\title{
Technology: Technological Advances and Changes in Human Lifestyles in a Socio-Cultural Perspective
}

\author{
M. Khoirul Hadi al Asy ari ${ }^{1, *}$, Muhammad Rahman ${ }^{2}$,** \\ Santri Ma'had Aly IAIN Jember and Lecturer Staff of the IAIN Jember Faculty of Sharia and Nurture the IMC Study Community IAIN Jember, \\ Islamic Economics Law Study Program Student IAIN Jember \\ Email: hadiariiainjember@iain-jember.ac.id*,mr339514@gmail.com**
}

\begin{abstract}
The development of technology in this day and age can not be denied anymore, technology is very fast and rapid development. So it is not surprising that the need for media technology is increasingly high, with the existence of various jobs technology is very easy and quickly done. From that we wrote this paper aims to: (1) know the process of development of technological progress, (2) find out changes in human life patterns due to technological advances, (3) find out the influence of technological advances in the socio-cultural field, and (4) get solutions in overcoming negative impact of technological progress. This paper is the result of a literature study sourced from books, articles, journals, and completed with survey results on the use of modern technology used as data collection techniques. The data obtained were analyzed descriptively critically by the author using the socio-cultural theory change approach. The results of the discussion in this paper show the following: (1) technological advances continue to develop very rapidly and give birth to digital society; (2) there is a change in the pattern of human life due to technological advances so that it becomes more pragmatic, hedonistic, secular, and gives birth to an instant generation but also prioritizes the effectiveness and efficiency in their behavior and actions; (3) technological advances are double faced because they have positive and negative effects on human life; (4) efforts to reduce and overcome the negative impacts of technological progress can be made by synergizing the roles of family, education, society and the state. With data collection methods, documentation and participation in case studies. To obtain maximum and concrete results, this paper can be used as a solution to various problems related to technology.
\end{abstract}

Keywords: Technology, Lifestyle, And Socio-Cultural Change.

\section{INTRODUCTION}

Humans use technology because they have reason. With his mind humans want to get out of trouble, want to live better, safer, and so on. And technological developments occur because of someone using their minds to solve every problem they face. Technological progress is something that can not be avoided in this life because all people need the name of technology, because technological progress will go according to the progress of science. Every innovation will be created to provide a positive benefit for human life. And technology also provides many conveniences, as well as a new way of doing human activities very quickly to do work.

Humans have also enjoyed the many benefits brought about by technological innovations that have resulted in this new era. In the current era of globalization, mastery of technology is an achievement and indicator of the progress of a country. One of them, the State is said to be advanced if it has a high level of technological mastery (high technology), whereas countries that cannot adapt to technological advances are often referred to as failed countries. Here are 10 countries in the world that succeed with mastery of high technology (table 1).

Countries that prospered became superpower (powerful), wealthy (prosperous), and prestigious (prestigious) because of the capital of technology. Because of that, entering the Third Millennium, it is not surprising to develop a desire to utilize, develop, and master technology.

Table 1. 10 of the World's Greatest Countries in 2012.

\begin{tabular}{l|l}
\hline No & Country \\
\hline 1 & Finlandia \\
\hline 2 & Amerika Serikat \\
\hline 3 & Swedia \\
\hline 4 & Jepang \\
\hline 5 & Korea Selatan \\
\hline 6 & Belanda \\
\hline 7 & Korea Utara \\
\hline 9 & Australia \\
\hline 10 & Singapura \\
\hline
\end{tabular}

Technological breakthroughs in the fields of microelectronics, bio-technology, telecommunications, computers, internet and robotics have fundamentally changed the way we develop and transform technology into the production sector that produces goods and services with high technology (Buhal). On one hand, the rapid development of the science and technology world has brought tremendous benefits to the progress of human life. The types of work that previously demanded sufficient physical abilities are draining, now it is relatively easy because it is helped by the existence of automatic and sophisticated machines that help ease the 
job. Likewise the discovery of new formulations of computer capacity, as if it was able to shift the position of the ability of the human brain in various fields of science and human activity. the conclusion said the progress of technology today has really been recognized and felt to provide a lot of convenience and comfort for the lives of humanity (Dwiningrum,). On the other hand, humans cannot deny that technology also has a negative impact on humans themselves. Technological advances, which were originally to facilitate humanity, when the matter became easier, then "loneliness" and a new alienation emerged, namely the fading of solidarity, togetherness, and friendship among each other. For example the discovery of television, computers, internet, and cellphones has resulted in complacent with the world of the screen. The screen then becomes a loyal friend, even we pay more attention to the world of the screen than his wife / husband, and children though. Almost every time we wake up we press the television button to see the screen, go to the office press the cellphone button to see until we forget the time spent only used for the screen and not see people around him.

As a result, the relationship between family members drift apart from each other because they are engrossed in their respective screens. This is new in one's own household, especially with neighbors, maybe meeting neighbors only when a white flag (sign of death) stands in front of a neighbor's house. At that time, we realized that a neighbor had died. With a little ado we visit briefly before going to the office (Bakhtiar,). screen technology is able to anesthetize humans to submit to the screen and ignore the others around them. If humans are not aware of this, then they will be lonely and lose something very important in themselves, namely togetherness, family relationships, and warm social. If the influence of technology is growing rapidly, humans are not aware of their true needs. Humans today have truly become slaves to technology. Based on a survey conducted by Secur Envoy, a company specializing in digital passwords, which conducted a survey of 1,000 people in the UK concluded that today's students experience nomophobia, which is anxiety and fear if they are not with their cellphones. The survey results show, 66 percent of respondents claimed they could not live without their cellphones. Of the percentages that have been studied this is increasingly swollen in respondents aged 18 and 24 years. Of the 77 percent of respondents who among this age group experience nomophobia.

Meanwhile, other research conducted by Zogby International in the United States shows that 24 percent of 1,950 respondents consisting of adults stated that the internet had a significant impact on their lives both in terms of good and bad. According to the research company, most people said they could not live without the internet and needed high-speed connectivity. As many as 22 percent of the study participants claimed to access Facebook while online and another 10 percent visited the Google site that was the site most frequently used. When asked their predictions about future information technology, 40 percent of respondents imagined that in the next few years a chip would be planted on the bodies of all citizens of the world. This chip serves to monitor the health condition and detect the presence of the person. Some of them also believe that the work done by humans will turn to robots. And Zogby revealed that technological advances will also be felt in the field of health, especially in the development of cloning techniques for creating human organs and cell systems in medical science, technology is very useful and helps a lot in terms of treatment.

\section{MATERIALS AND METHODS}

This research uses a qualitative research method. Qualitative research methods which are defined by Social Sciences research methods that collect and analyze data in the form of words (oral and written) and human actions and researchers do not try to calculate and quantify the qualitative data that has been obtained and thus do not analyze the numbers .

This study provides an overview of social reality, therefore this research is descriptive. Descriptive research is research that describes a phenomenon or social reality relating to the problem and unit under study. The use of this method provides the opportunity for researchers to collect data sourced from interviews, field notes, photographs, personal documents, notes and memos to illustrate the subject of research.

\section{RESULTS AND DISCUSSION}

Concept of Technology Humans at first did not know the concept of technology as it is now. The presence of early humans in prehistoric times, only knew technology as a tool in his assistance in finding food, aids in hunting, and processing food. The tools used are very simple, made of bamboo, wood, stone, and other simple materials that are easily found in the wild. For example, to make a fireplace, he uses rocks that can cause sparks. In the beginning, technology developed slowly. But along with advances in the level of culture and human civilization technological development is developing rapidly. The more advanced the culture, the more developed the technology because technology is the development of a rapidly advancing culture (Adib).

Technology literally comes from Greek, which is "tecnologia" which means a systematic discussion of all arts and crafts. The term has the root word "techne" in ancient Greek meaning art (art), or craft (craft). From this literal meaning, shows that technology in ancient Greek can be defined as the art of producing means of 
production and using them. The definition then develops into the use of science according to human needs.

Henslin also explained that the term technology can cover two things. First, and technology refers to equipment, which is an element that is used to complete a task. Technology refers to equipment so simple - like a comb - that is very complicated - like a computer. Second, the skills or procedures needed to make and use the equipment. The technology referred to in this issue not only refers to the procedures required to make combs and computers, but also includes a procedure for producing an acceptable hairdo, or to be able to enter the internet network. Sociologically, technology has a deeper meaning than equipment. Technology can establish a framework for the nonmaterial culture of a group that can be collaborated with matrial culture. If a group's technology experiences a change, then the way of human thinking will also change. This also impacts the way they relate to others.

For Marx, technology is a tool, in view of historical materialism, only refers to a number of tools that humans can use to prosper. Weber expressed technology as an idea or the human mind itself. whereas according to Durkheim, technology is a collective consciousness that is even predicted to replace the position of religion in a society that is gradually being left behind. Technological developments will undergo several cycles. Jacob explained several cycles of the development of science and technology into five stages. The five stages are stated as five conductive cycles, which is a cycle that will repeat every 50 years. The five cycles are: first, starting with the technological revolution (1760); second, marked by the expansion of the railroad network (in 1848); third, starting with the discovery of a conveyor belt (1895); fourth, marked by the discovery of atomic energy and mass motorization (in 1945); and fifth, with the development of micro-electronics and biotechnology. Technology easily shows its phenomenon in society as impersonal and has the autonomy to change every area of human life into a technical sphere. With the technology of community life can be changed and helped. And Sastrapratedja (Dwiningrum, 2012, p.154) revealed that the technical phenomena in today's society, have the following characteristics:

a. Rationality, means spontaneous actions or opinions based on logical and rational thinking.

b. Artificiality, it means always making something unnatural or artificial.

c. Automatism, which means that in terms of methods, organization, and formulation is carried out completely automated. Similarly, techniques that are able to eliminate non-technical activities into technical activities.

d. Techniques develop in a culture.

e. Monism, which means that all forms of technique are united, interact and are interdependent. f. Universalism, meaning that technique transcends cultural and ideological boundaries, can even master culture.

g. Autonomy, meaning that techniques develop according to their own principles.

A technology that is developing rapidly, and is fast spreading over various fields of human life. Nowadays, human life cannot be separated with technology, even technology is part of human needs. The beginning of technology is part of science, now it can be inversely proportional to science that depends on technology. For example, with the rapid discovery of computer technology and space satellites, new knowledge is obtained from the work of these two technology products.

Based on the description above it can be concluded that technology is the result of human thought, which in the end the technology is used for various purposes in life. Technology is also the result of the development of human rationality. Technology is the result of the development of human rationality. When the existence of technology is developed in the structure of human action, the existence of this technology is also placed within the framework of the development of human rationality. When humans are still in the irrational stage or are traditional and affective, humans are able to produce various technologies that are still traditional. Along with the development of rationality, humans have produced a variety of technologies that are quite sophisticated, but with the achievement of sufficiently sophisticated technology, humans finally take advantage of their existence to achieve the goals of the existence of such technology.

Technology has made the human mindset itself, and consequently technology also influences human actions and mindsets. The broad ability of technology is also interpreted in distinguishing classes in society. Who is capable of mastering technology, so he is able to master other humans, with the concept of new technology will have an important impact on social life.

For people who lived 500 years ago, new technology only refers to the printing process. Whereas at present, new technology refers to satellites, aircraft or other communication technologies. Changes in human life that were originally based on agriculture to be industry based are also very influenced by technological developments. The promise of technology is something that needs special attention, that every technological development always promises ease, efficiency, and increased productivity. It is true that a technology from the beginning was created to make it easier for humans to meet all their needs. Here are some things that technology promised to be used:

a) Technology promises that any new technological discovery will give birth to new changes in society. And in the presence of a technology presence subsystem is very helpful as new ideas in society will 
bring consequences, other subsystems in the system will inevitably have to adjust due to the presence of the technology. Technology will definitely change the pattern of life or individual activities. The presence of television at home for example, will cause a new agenda to appear every day, there is a schedule of watching favorite shows that did not exist before. Bath schedule, meal schedule, coffee drinking schedule, cleaning house schedule, study schedule, dating schedule, until the sleep schedule will be adjusted to the television program schedule. Even the arrangement of furniture at home, tables, chairs, cabinets, carpets, sofas, will be adjusted to where we put the television.

b) Technology promises progress Technology is a symbol of progress. Anyone who is able to access technology, then he will experience little or much progress in any direction. With technology someone will not miss an information. Technology also influences lifestyles and even technology becomes a lifestyle itself.

c) Technology promises convenience Technology is indeed created to provide convenience for individuals. One does not need to bother to contact relatives outside the city, even abroad; with their technology enough to use mobile technology to contact distant relatives. And out there People don't need to queue in front of the bank teller to do all the transactions, easily just enter the ATM room and we can make various transactions using the machine, start taking money, paying electricity, water, telephone, buying credit, buying credit train tickets, planes, ships, pay tuition, send money to other accounts, to pay credit bills. When we are hungry, we simply press a number of the order delivery, then in a few minutes, the food delivery officer arrives at our doorstep. We can use airplanes to travel long distances in a short time; we don't need to go to the trouble of going up to a higher floor in a multi-storey building, we just need to use an elevator or escalator.

d) Technology promises to increase productivity Large companies use technology for reasons of efficiency and increased productivity rather than having to employ human workers who take up a lot of budget to pay them. Technology can also increase company profits by multiplying as well as a control tool to evaluate one's performance. Finger print technology (presence system using fingerprints) for example, will be able to control the level of employee attendance at the office.

e) Technology promises speed Various jobs will be completed quickly when we utilize technology. The existence of a computer will help speed up work in the office, speed up bookkeeping, technology will also speed up the process of sending documents, letters or files, and goods. Cooking rice will be faster if you use a rice cooker. All work will be easier to do and quickly overcome with technology.

f) Technology promises the popularity of Humans easily appear on the screen through the internet. Youtube, IG, fb site or application that makes it accessible to news or as a media for us to show our identity to the public. Existing technology such as existing sites can be used as income for someone if used according to good intentions.

Most of the Digital Era modern era must be identified with the era of digital society. Every movement of human activity will be driven through a series of sophisticated digital technologies. This technology is operated by pressing several digits (numbers) arranged in various sequences. A relation that can be built up between individuals is a digital exchange relationship, each human being only does a series of transactions or interactions through digital symbols. Trade transactions, communications, everything is digitally driven. Every individual will have a digital identity that is able to recognize who he is, every human being has been given a serial number: through an identity number (e-KTP), mobile number, telephone number, bank account number, ATM number, electricity account number, telephone account, water account, PIN (Personal Identification Number) ATM, all of which use a digital system. Interaction between humans is driven by alldigital technology: computers, internet, ATM machines, telephones, and others. We can buy something just by swiping an ATM card and pressing a number of PIN numbers, as well as paying for hotel room bills, buying tickets, and so on. Sending money can be done in seconds by pressing a few digits of the value of the money to be sent and several digits of the destination account number. Not money sent, but only a series of numbers that move from one account to another account.

Theory of Socio-Cultural Change Sociologists and anthropologists have different opinions about social change including:

1. Gillin and Gillin, interpreting social change is a variation of the way of life that has been accepted, both because of changes in geographical conditions, culture, composition of the population, and ideology as well as because of diffusion or new discoveries in society.

2. Larson and Rogers, put forward an understanding of social change associated with the adoption of technology, namely social change is a continuous process in a certain time span. The use of certain technologies by a community member will bring a social change that can be observed through the behavior of the members of the community concerned.

3. Soerjono Soekanto, defines social change is all changes that occur in social institutions in a society, which affect the social system. 
The symptoms that can cause social change have characteristics, among others: First Every society will not stop developing because they experience changes both slowly and quickly. second Changes that occur in certain social institutions will be followed by changes in other social institutions by following changes in that institution. Third, rapid social change can lead to temporary disorganization as a process of adjustment and adaptation to new things. The four changes are not limited by the material or spiritual realm because both have strong reciprocal relationships. From the discussion above it can be concluded that social change, culture can involve many aspects of life such as art, science, technology, and philosophy. So, technology is one of the factors that influence social cultural change. Social change has three dimensions, namely: structural, cultural, and interactional. First, the structural dimension refers to changes in the structure of society, regarding changes in roles, the emergence of new roles, changes in the structure of social classes, and changes in social institutions. Second, the cultural dimension refers to cultural change in society. These changes include; (1) cultural innovation, is an internal component in a society. The most easily found cultural innovation is the emergence of new technology. The increasingly complex needs of society force individuals to think creatively in an effort to meet those needs. (2) diffusion, is an external component capable of driving social change. A culture gets influence from other cultures, then triggers cultural changes in a society that "accepts" the elements of that culture. (3) integration, is a form of "relatively more subtle" cultural change. This is because in this process there is a unification of cultural elements that meet each other to then bring up a new culture as a result of the unification of various cultural elements. Third, interactional dimension refers to a change in social relations in society that is always changing at any time without any adjustment first. These dimensions include :

a. Change in frequency. Technological developments have led to a reduction in the frequency of individuals meeting each other face to face. From all forms of interacting needs can be met by utilizing technology. A bank customer does not need to repeatedly meet with bank teller officers. The function and role of bank tellers has been replaced by the existence of an ATM machine (Automatic Teller Machine) that is able to serve customers for 24 hours anywhere, anytime, without having to queue for a long time, or write certain forms.

b. changes in social distance, the development of information and communication technology has shifted the function "face to face" in the process of interaction. Individuals do not have to face to face to be able to communicate and interact directly. Even when two individuals are very far away, they can still communicate even within thousands of kilometers.

c. Intermediary change. The mechanism of individual work in many modern societies is completely "online", causing individuals to not need much "other people" in the process of sending information. In earlier times, when a king who wanted to deliver news to the neighboring kingdom, then had to send soldiers to deliver a letter to the neighboring kingdom to be delivered to the neighbor. However, in the modern era now to convey information between countries can be conveyed through other people as intermediaries.

d. Changes to rules or patterns. Many rules and patterns of relationships that change with the development of society. The emancipation of women in the world of work, for example, has changed the way people look at responding to "women returning home at night". Whereas previously women who often go out or come home late at night were often connoted as "bad women", but now the community has seen this as a normal thing because at present many women work late into the night or even work at night.

Changes in the form of interactions, and interactions between individuals today are not as rigid as in the past when interactions must be done face to face and actively interact with each other. In this era, to interact with other people can be done at any time by using technology in the form of mobile phones or other internet.

Social change is divided into two forms as follows: a). Change in the meaning of progress. b) changes in the meaning of setbacks, that is, which have unfavorable effects on society. If change progresses, society will develop. Conversely, if change does not develop, people's lives will decline. And technological progress on one hand is an example of social change that is progressive because it facilitates human activities in meeting their needs both primary and secondary. However, on the other hand technological progress is also an example of social change that is setback because humans become dependent on technology (technology slaves) not humans who master technology but technology that controls humans due to the emergence of laziness in doing a job with the existence of technology that simple and practical work without draining a lot of energy.

Likewise Changes in Human Life Patterns Due to Technological Progress Previously, the farmers in my neighborhood still use the help of animal power in working / plowing their fields and also assisted by neighbors in planting rice or other crops. But now, with the development of technology, farmers have used tractors in plowing the fields and have also used rice threshing machines to process their crops. In addition to technology in agriculture, technology related to communication is also developing rapidly. In the past, if you want to communicate remotely requires a long time. However, communication tools are now sophisticated. For example, through a cell phone that currently one person does not only have one such communication device. In fact, now even teenagers who are still children 
already know what Facebook, email, Twitter, and so on. The pattern of human life always changes along with the times. This increasingly modern life makes different patterns of human behavior. For some people lifestyle is an important thing because it is considered as a form of self-expression. And patterns of life are patterns of action that distinguish between one person with another person with that pattern each group of people will be different from other groups, which functions in interactions with ways that may not be understood by people who do not live in modern society. Talcott Parson's opinion, that modern society is described with the following characteristics: a. Effective neutrality is being neutral, even leading to attitudes of not paying attention to others or the environment. b. Selforientation, which is more concerned with self-interest. c. Universalism, which is to accept everything objectively d. Achievement, namely the people like to pursue achievement. e. Specificity, that is being straightforward in expressing everything.

Likewise with the role of technology in influencing changes in human lifestyles is not a question that needs to be questioned again because there is a lot of evidence that states technology is the latest human civilization. Humans will not be able to live without technology. Ancient humans, for example, have long known technology as a tool to meet their needs, most of the technology is made from materials or very simple materials. Technology can unite the community, it can also separate the community. There are four changes in thinking tendencies caused by technological development, namely: first, the growth of reification, namely the assumption that the wider scope in reality must be realized in outward forms and measured quantitatively. Second, manipulation, which is a high manipulation ability for human frame of thinking caused by the ability of technology to change and process natural objects into something that is artificial to meet human interests. Third, fragmentation, namely the existence of specialization in the division of labor which ultimately demands professionalism in the world of work. Fourth, individualization, which is characterized by the increasingly loose ties between a person and his community and the greater role of individuals in daily behavior (Martono,). in the current technological era humans are so far influenced by engineering. The description of these conditions is as follows: a) Depressed situation. Humans experience tension due to absorption of technical mechanisms. Humans merge with technical mechanisms, so that human time and work experience a shift. From the presence of human fusion with technical mechanisms, will demand a quality from humans, but humans themselves are not present in it. For example: in the tire industry system, a worker even though sick or tired, or there is sad news that his child is dying in the hospital, maybe the work cannot be abandoned because it will jam the production line and wages for his friend. From such depressed circumstances, the human self will eliminate social values and are no longer human. b) Changes in human space and environment. Engineering has changed the human environment and human nature. From a simple example human beings in terms of eating or sleeping are not determined by hunger or sleepiness but are regulated by the clock. The human environment is limited, people are now only associated with dense tall buildings, so the morning sun does not have time to touch the surface of the skin of the human body. c) Changes in time and human motion. As a result of technique, humans are independent of the nature of life. Until before that time was arranged and measured according to the needs and events that exist in human life, natural and concrete. But now time is abstract by dividing hours, minutes and seconds. The quantity of time used by humans is not human or social because life is now more timedependent and not humans themselves who use time. d) The formation of a mass society. As a result of technique, humans only form a mass society, meaning that there are gaps as a collective society. And now the structure of society is only determined by economic law and is more passive, political, and class competition more prominent. This process has eliminated the values of a community's social relations. The occurrence of obsessive neuroses or nerve disorders according to some experts is a result of the loss of the values of social relations. From the current condition, humans are often seen as objects of technique and must always adapt to existing techniques as if humans are driven by techniques to be helpless by them (Bachtiar). e) It turns out that the modern world carving out success stories materially and rich in science and technology, seems not enough to provide a solid provision of life for humans, so that many modern humans are lost in their progress and modernity. Modern humans lose the moral aspect as a function of control and are trapped in a technological cage. Based on the theory of socio-cultural change technological advances have led to both progress and setbacks in socio-cultural life.

Effects of Technological Advancement in the Field of Socio-Culture Several forms of changes in social and cultural behavior due to technology include the following:

1) Differences in male and female personalities. Many experts are of the opinion that there is now an increasingly large portion of women holding leadership positions, both in government and in the business world. And even the change in behavior toward behavior that was previously the work of men is increasingly prominent and shows the difference.

2) Increased self-confidence. And economic progress in Asian countries gave birth to an interesting phenomenon for the people of developing countries. From the development and progress of the economy has increased self-confidence and self-defense as a 
nation will be more solid in the wealth of the country. Western nations can no longer harass Asian nations. Because the Asian countries themselves have gradually increased their development and progress in the economy.

3) A pressure, from a sharp competition in various aspects of life as a consequence of globalization and technological progress, will give birth to a generation that is disciplined, diligent and hard-working in various aspects.

Technology in addition to having a positive influence also has a negative influence on the socio-cultural aspects, among others: first, moral deterioration among citizens, especially among adolescents and students. The progress of economic life that places too much emphasis on fulfilling various material desires will increase the enthusiasm of the plural society which has caused some citizens to become rich in material but poor in spirit. Second, delinquency and deviant acts among adolescents are increasingly increasing the weak authority of traditional traditions that exist in society, such as mutual cooperation and help has weakened the power of centripetal forces that play an important role in creating social unity. As a result, many adolescents are increasingly behaving deviant, such as fighting, scribbling, or violating traffic rules or even crime. Third, patterns of interaction between people are changing. The presence of a computer technology in most middle and upper class households has changed the pattern of family interactions that are usually passive to become more creative. A computer connected by a telephone has opened opportunities for anyone to connect with the outside world. The Internet Relay Chat (IRC) program, the internet and e-mail have made people absorb in their own lives. In addition, the availability of various internet cafes (warnet) has provided opportunities for many people who do not have their own computers and internet channels to communicate with others through the internet. And now with technological advances more and more people are spending their time alone with computers. Through the Internet Relay Chatting (IRC) program, children can have fun chatting with friends and strangers anytime anywhere without having to meet each other (Siti Irene).

Various Solutions to Overcome the Negative Impacts of Technological Progress Technological advancements are part of the consequences of modernity and human existence on earth. Therefore, the negative impacts arising as a result of technological progress become an obligation for humans to overcome them. With this shared awareness, future generations will grow smarter and more dignified. The following outlines the roles that should be carried out by families, schools (educational institutions), communities, and countries to suppress and overcome the negative effects of technological progress on postmodern society. The family roles include the following. 1), the family as the person who first plays the role of accompanying and limiting children by introducing good values and norms so that they can provide a strong faith for children. That, too, is the foundation to bring God closer to the child. 2), families must be selective in determining the priority scale of technology needs for families. This is done in an effort to reduce the way of life of modern humans who tend to be consumptive to technological products. In addition, determining the priority scale is needed so that the technology used really provides great benefits for the family. For example, if you already have a television, you don't need to buy another television for each family member. 3), parents must update on technological developments so that they do not catch up.4), the need for guidance and supervision from parents to their children in the use of technology, especially information and communication technology such as television, cellphones, computers and the internet.

Efforts can be made in the following ways: first, Limiting the channels (channels) of television that enter so that shows that bring negative impacts on children, especially pornography, and violence, especially on children. Second, Accompanying children while watching television so that we can direct the child that not everything that is seen on the screen is a real event. Third, parents check their children's cellphones incidentally to ensure that they use communication technology properly and responsibly. Fourth, Trying to put computers and internet channels in public spaces at home such as in the family room not in the child's room. This is intended to make it easier for parents to supervise children's activities. Fifth, Block internet sites that are harmful to children's development. Sixth, parents come to be friends of children in online social media. Seventh, Make an agreement with children about playing time on the computer and the internet.

This is needed so that when they grow up they can be disciplined and able to manage time well. In addition, an agreement on time can prevent children from being addicted to computers and the internet and can save expenses. 5) Parents take time to gather, play, and chat with family members. Thus good interactions will be established so that harmonization of relationships within the family can be maintained. 6) Raising awareness to children about the negative impact of technology on their lives in the future. This effort can be done by giving freedom to children in utilizing technology but it must be accountable.

The role of the school is as follows. 1) As an institution that plays an effective role in tackling the negative impacts of technological progress, schools need to establish a clear set of rules or school rules for students regarding the use and use of technology in schools. For example, schools forbid junior high school students from bringing mobile phones to school. This rule aside from avoiding undesirable things (theft of mobile phones) also means that students focus more on learning in school. 2) In learning, the teacher always 
gives outreach and emphasizes the benefits and adverse effects of technology for children. Thus students are expected to be wiser in utilizing technology. 3) Considering the use of information technology in education, especially for minors who still have to be supervised while doing learning with information technology. Schools should analyze the advantages and disadvantages of using these technologies for students. 4) So as not to make information technology as a medium or the only means in learning methods that will reduce the process of reading books in the library. 5) Teachers should provide ethical teaching in information technology so that information technology can be used optimally without eliminating ethics. 6) Using software specifically designed to protect the "health" of children. For example, in a nany chip or parent lock program that can protect a child by locking various sites that will be accessed that smells of sex and violence that are not suitable for young children to watch. 7) Teachers must be able to become role models for students in responsible, proportional and professional technology. For example, a teacher does not bring a cellphone and pick up the phone while teaching, the teacher does not play online games or Facebook and twitters when students are asked to do assignments because it will make the teacher not too respected by the student. 8) Schools become pioneers in the use of environmentally friendly technology in sustainable development efforts. For example, using generators that have low emission levels and using sound absorbers so that it does not cause noise that interferes with learning activities, and utilizes damaged computer hardware as a teaching aid. 9) and the School provides computer and internet extracurricular activities so students do not miss the technological advancements that have rolled out there. In addition, schools can also carry out extracurricular activities in technological skills so that students are not only proficient as end users of technology but are expected to be able to have creative, innovative ideas in finding appropriate technology in a simple scope.

The role of the community include the following. 1) Communities in their capacity as technology consumers should need to filter technology entering the community so that it is not misused in its use for early childhood. In the era of globalization, of course the people do not have to be like the inland Bedouin tribe (Banten) who are antimodern technology so that they are left behind from other communities, but our society must also be aware that we as eastern societies must be able and clever in digesting technology that is beneficial to the progress of our society. 2) and in his capacity as an active producer of technology products in the field of technology society should not only prioritize market oriented and profit oriented, but need to think about the impact of these technology products in some ways for our society specifically and the world community in general to be able compete with outside communities. This means that the technology developed should aim to improve human civilization not to destroy it. For example, nuclear technology was developed to overcome the scarcity of electricity fuel not for weapons of mass destruction. 3) all practical community efforts that can become fields of income and family independence, among others: a) Creating a website / blog / facebook group for a particular community that is positive (for example: the Yogyakarta community group) as a medium of interaction and efforts to establish friendship for fellow citizens. b) Make special rules regarding licenses to set up internet cafes (internet cafes), online games, and play stations so as not to cause unrest and turmoil in the community. c) Holding a "watch together" event at certain events. For example a soccer match. Thus the community can interact with each other and strengthen intimacy with each other even though they rarely meet, kinship, and unity. d) Hold regular meetings at the RT and village / kelurahan level as a means of direct interaction and socialization to the community, especially in making a consensus on order, security, and comfort of the community related to the use of technology. For example, motorcyclists must walk slowly when entering the village, and turn off the motorcycle engine when entering the alley above 22.00. e) Utilizing technological advancements such as the internet to market superior products (clusters) and introducing local culture so that it will be recognized by the wider community and even the world which has an impact on improving the level of the economy and people's welfare.

The roles of the state are as follows. 1) As regulators and state facilitators, they should make special regulations to limit websites on the internet that have the potential to damage the morality of the Indonesian people. Such as the existence of government agencies through the MOCIT to carry out a blocking action against pornographic sites that are not useful, criticize and act against writings or articles nuanced SARA such as criticism of making caricatures of the Prophet Muhammad, or the film Innocense of Muslim recently made by United States people to denigrate Muslims. 2) Make strict rules and sanctions against internet abuse and internet crime. For example, giving penalties to pornography perpetrators and spreaders, in collaboration with Interpol to prevent and handle cases of internet crime (cyber crime). 3) The government must be a good example for the community in technology that is wise, economical, and environmentally friendly. For example, state officials do not waste money on expensive official vehicles, are not wasteful in using electricity, and do not abuse power and positions to obtain special facilities in technology. 4) and Make an appropriate policy related to the progress of transportation technology to make it more convenient for the community to use. for example, fuel subsidies (Premium BBM) are only used by transportation vehicles, and two-wheeled vehicles, as 
well as vehicles with special criteria, and limit the ownership of vehicles both two-wheeled and fourwheeled to reduce pollution and congestion levels, set standards for emissions levels of vehicle exhaust emissions without engineering and negligence, set a maximum limit on vehicle load (tonnage) without illegal levies from certain officers or persons, provide better mass transportation facilities, and run a more efficient and sustainable fuel conversion program. 5) By Developing Research and Technology Institutions (Research and Technology) as an effort to achieve the independence and progress of the nation which is more realized. For example, to strengthen the aircraft industry (IPTN), steel or steel, Pindad, automotive (Esemka car tips), and other industries that allow it to be developed. 6) Do not sell strategic state assets such as communication, mining, oil to foreign nations, which in turn results in excessive dependence on foreign nations. 7) Strengthening agricultural technology to achieve food self-sufficiency so that we are not likened to "rats that die in rice barns". 8) Increase the promotion of culture and tourism by utilizing information technology to help increase non-tax state revenue. 9) Likewise Strengthening the populist economic sector and cooperatives in order to prevent the existence of foreign capitalism due to industrial progress and the rapid technological diffusion of its development. 10) Making policies related to the national education curriculum which is oriented to the inculcation of national character and culture values, which has a global perspective. This effort is intended to prepare the next generation of nation that is reliable, with high technology mastery, has global competitiveness but still shows the identity and personality of Indonesia. 11) Strategies for the development of science and technology (IPTEK) that are not value-free but value based (based on values), especially religious values and noble values of culture and national personality. This is intended so that in this technological age we will continue to be a religious and superior personality nation, not to become a secular nation that glorifies technology and negates God in its life activities.

\section{CONCLUSIONS}

Sociologically, a technology is one aspect that also influences every human activity, action, and behavior in daily life. Technology is also considered capable of changing patterns of relationships and patterns of interaction between people. The presence of technology is something that can not be separated from human life. And various human activities will more or less be influenced by the presence of technology that has been scattered all over the earth. Today's technological advances are characterized by increasingly sophisticated tools in the fields of information and communication, satellites, biotechnology, agriculture, equipment in the field of health, and genetic engineering. The emergence of digital society in various fields of life is evidence of technological progress. Communities and countries in the world are competing to be able to master high technology as a symbol of progress, power, wealth and prestige. In reality Postmodern society applies the law 'whoever is capable of mastering technology will rule the world'. In the era of globalization, technological progress is so fast that sometimes people do not have time to adapt to these advancements. As a result, anomy occurs in the community because they do not have a clear grip on life. While people who are not able to master technology will experience cultural lag and their existence will be threatened because they cannot adjust to the situation and lag behind others. From the advancement of technology, it is like two sides of a united currency, where on one side the advancement of technology provides many positive benefits for humans to make it easier for humans to fulfill their daily needs which will change and increase every day. However, similarly, on the other hand, technological progress has a complex negative effect that exceeds the benefits of the technology itself, especially related to the pattern of human life in the social cultural dimension. Technology threatens death through various diseases, environmental damage, global warming, creates tension, presents various risks, shackles human beings through a hidden control system, and dehumanization. And one thing we need to remember as a foundation for us, that technology is always double faced, at one time he became a friend, at another time, he can also be an opponent who can knock us down.

All efforts that we can do as a solution to overcome the negative impact of technological progress is to instill awareness to each individual about the importance of understanding the negative impact of technological progress that can neglect us towards something more important. With a simple SWOT analysis we can make the challenges and negative impacts of technology an opportunity to advance a society and country. For this reason, active participation from families, schools, communities and countries is needed in preventing, reducing and overcoming the negative impacts of technological progress. As modern humans is very unwise and impossible if we say say no to technology, but what we have to do is consider our needs for technology, consider the merits of the technology and keep using ethics, and not too much so that we are not addicted and become technology slave. And also We have to realize that technology is not the highest and most trusted aspect of human life because it also has many negative effects on us. And Nor is it the pinnacle of human culture and civilization in its evolution to reach the perfection of life because there are still more in accordance with human civilization. However, a technology is a tool used by humans to make it easier to do something in their life activities and is to help ease 
the work rather than being the most important aspect in human life.

\section{REFERENCES}

Adib, Mohammad. (2011). Filsafat ilmu: onto-logi, epistemologi, aksiologi, dan logika ilmu pengetahuan. Yogyakarta: Pustaka Pelajar.

Bachtiar, Amsal. (2012). Filsafat ilmu edisi revisi. Jakarta: Raja Grafindo Persada.

Buhal. (2000). Visi Iptek memasuki milenium III. Jakarta: UI Press.

Dwiningrum, S. I. A. (2012). Ilmu sosial \& budaya dasar. Yogyakarta: UNY Press.

Martono, Nanang. (2012). Sosiologi perubahan sosial: perspektif klasik, modern, postmodern, dan postkolonial. Jakarta: PT. Raja Grafindo Persada.
Meinita, Hanna. (Diambil pada tanggal 1 Februari 2013). Mahasiswa tak bisa hidup tanpa smartphone. http://kampus. okezone.com/read/2012/03/26/373/599 857/mahasiswa-takbisa-hidup-tanpasmartphone.

Rini K. (Diambil pada tanggal 1 Februari 2013). Survei: tak bisa hidup tanpa internet. http://www.tempo.co/read /news/ 2010/12/23/072301058/SurveiTak-Bisa-Hidup-TanpaInternet.

Soerjono Soekanto. (1990). Sosiologi suatu pengantar: edisi baru keempat. Jakarta: Rajawali Pers.

Sukplang, Sukree. (Diambil pada tanggal 3 Februari 2013). 10 Negara terhebat di dunia. http://top10newsworld.blogspot.com/20 12/11/10-negaraterhebat-didunia.html.

Zamroni. (2008). The Socio Cultural Aspect of Technological Diffusion a Reader Volume IV. Yogyakarta: Pascasarjana Universitas Negeri Yogyakarta. 